
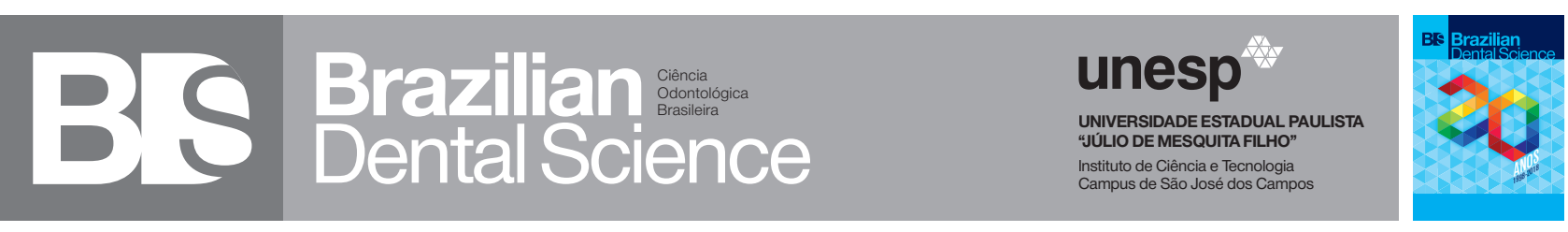

\title{
Comparison of different final irrigant agitation techniques for the removal of Enterococcus faecalis biofilms from root canals: an in vitro study
}

\author{
Comparação de diferentes técnicas finais de agitação de irrigantes para a remoção de biofilmes de Enterococcus faecalis \\ de canais radiculares: estudo in vitro

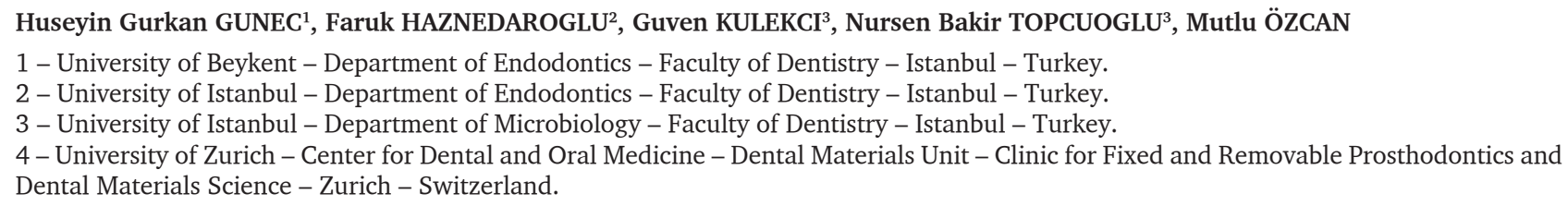

\section{ABSTRACT}

Objective: The aim of this in vitro study was to compare the effectiveness of different final irrigant agitation techniques in the removal of Enterococcus faecalis biofilms from root canals. Material and Methods: In total, the root canals of 85 extracted single-rooted human maxillary incisors teeth were prepared using the Revo-S system to a 40/06 size. The apical foramen of each tooth was sealed by photopolymerized resin composite material to obstruct bacterial leakage. The specimens were sterilized in an autoclave at $121^{\circ} \mathrm{C}$ for $15 \mathrm{~min}$ and stored until further use. All teeth except five (negative control group) were inoculated with Enterococcus faecalis and incubated in a $\mathrm{CO}_{2}$ chamber at $37^{\circ} \mathrm{C}$ for 7 days; the trypticase soy broth was changed every 2 days. To determine of possible biofilm formation, five of the 80 teeth were randomly selected as a positive control group; one tooth of positive control group was analysed for biofilm development by scanning electron microscope (SEM) and these teeth received no final irrigant agitation procedure. Then, the remaining 75 teeth were randomly divided into five test groups $(n=15$ each) and were sequentially irrigated with 5\% sodium hypochlorite $\quad(\mathrm{NaOCl}), \quad 17 \%$ ethylenediaminetetraacetic acid and 5\% NaOCl. Following each irrigant application, different final irrigant agitation techniques were introduced for $60 \mathrm{~s}$ ( $3 \times 20$-s sessions). Group 1 received manualdynamic agitation, group 2 received passive ultrasonic agitation (PUI), group 3 received EndoActivator agitation, group 4 received photon-

\section{RESUIMO}

Objetivo: O objetivo deste estudo in vitro foi comparar a eficácia de diferentes técnicas finais de agitação de irrigantes na remoção de biofilmes de Enterococcus faecalis de canais radiculares. Material e Métodos: No total, os canais radiculares de 85 dentes incisivos superiores unirradiculares humanos extraídos foram preparados usando o sistema Revo-S para um tamanho 40/06. O forame apical de cada dente foi selado por material compósito de resina fotopolimerizável para obstruir o vazamento bacteriano. Os espécimes foram esterilizados em autoclave a $121^{\circ} \mathrm{C}$ por $15 \mathrm{~min}$ e armazenados até uso posterior. Todos os dentes, exceto cinco (grupo controle negativo), foram inoculados com Enterococcus faecalis e incubados em câmara de $\mathrm{CO} 2$ a $37^{\circ} \mathrm{C}$ por 7 dias; o caldo de soja tripticase foi trocado a cada 2 dias. Para a determinação da possível formação de biofilme, cinco dos 80 dentes foram selecionados aleatoriamente como grupo controle positivo; um dos dentes do grupo controle positivo foi analisado para o desenvolvimento do biofilme por microscopia eletrônica de varredura (MEV) e estes dentes não receberam nenhum procedimento final de agitação irrigante. Em seguida, os 75 dentes restantes foram aleatoriamente divididos em cinco grupos teste ( $\mathrm{n}=15$ cada) e irrigados sequencialmente com hipoclorito de sódio a $5 \%(\mathrm{NaOCl})$, ácido etilenodiaminotetracético a $17 \%$ e $\mathrm{NaOCl}$ a $5 \%$. Após cada aplicação de irrigantes, diferentes técnicas finais de agitação foram introduzidas por $60 \mathrm{~s}$ (3 x $20 \mathrm{~s}$ sessões). Grupo 1 recebeu agitação manual-dinâmica, grupo 2 recebeu agitação ultra-sônica passiva (PUI), 
initiated photoacoustic streaming (PIPS) with the Er:YAG laser and group 5 received conventional syringe irrigation. Colony-forming units (CFUs) were counted in samples from the positive control and test groups. Data were analysed using Kruskal-Wallis and post-hoc Mann-Whitney U multiple comparison tests. Results: E. faecalis elimination was significantly better in the experimental groups than in the positive control groups $(\mathrm{p}<0.001)$. Manualdynamic agitation and conventional syringe irrigation, showed no significant differences between the two groups. Conclusion: Essentially, CFU reduction was significantly greater in the PUI, EndoActivator and PIPS groups than in the manual-dynamic agitation and conventional syringe irrigation groups ( $\mathrm{p}<0.001)$, with no significant differences among the former three groups.

\section{KEYWORDS}

Enterococcus faecalis; Irrigant agitation; Irrigant solutions; Photon-initiated photoacoustic streaming; Passive ultrasonic irrigation. grupo 3 recebeu agitação EndoActivator, grupo 4 recebeu fotoacústica iniciada por fóton (PIPS) com o laser Er: YAG e grupo 5 recebeu irrigação convencional com seringa. As unidades formadoras de colônia (CFUs) foram contadas em amostras dos grupos controle positivo e teste. Os dados foram analisados utilizando testes de comparação múltipla Kruskal-Wallis e post-hoc Mann-Whitney U. Resultados: A eliminação de E. faecalis foi significativamente melhor nos grupos experimentais do que nos grupos de controle positivo ( $\mathrm{p}<0,001)$. Agitação manual-dinâmica e irrigação com seringa convencional, sem diferenças significativas entre os dois grupos. Conclusão: Essencialmente, a redução de UFC foi significativamente maior nos grupos PUI, EndoActivator e PIPS do que nos grupos de agitação manual-dinâmica e de seringa convencional ( $\mathrm{p}<$ 0,001 ), sem diferenças significativas entre os três grupos anteriores

\section{PALAVRAS-CHAVE}

Enterococcus faecalis; Agitação por irrigação; Soluções de irrigação; Fluxo fotoacústico iniciado por fotões; Irrigação ultrassónica passiva.

\section{INTRODUCTION}

E ndodontal diseases are basically caused by microorganisms present in the root canals of affected teeth. [1] The success of endodontic treatment largely depends on the removal of these microorganisms and their byproducts from infected root canals. [2] Cleaning and shaping procedures aid in the removal of these microorganisms and facilitate filling or obturation of the root canals, a procedure known as chemomechanical preparation. This procedure, in addition to mechanical cleaning using endodontic tools, involves the use of irrigation solutions that provide antibacterial and solvent effects. [3-5]

Previous studies demonstrated the presence of residual bacteria on root canal walls after cleaning and shaping, which was believed to be a result of a complex root canal anatomy that does not allow contact between cleaning tools and certain areas of the canal walls. $[6,7]$
Furthermore, several recent studies have shown that Enterococcus faecalis, a grampositive facultative anaerobe, plays the most important role in secondary and persistent root canal and periapical infections. [8-11] One of the reasons is the ability of this bacterium to form a biofilm, which is a highly sheltered structure containing other microorganisms. The formation of bacterial clusters on the walls of infected root canals-in other words-biofilm formation, has been reported, although detailed descriptions were not provided. [11,12] It is therefore necessary to completely eliminate this bacterium from infected root canals for successful endodontic treatment, [13] and irrigation during chemomechanical preparation and mechanical cleaning has been reported to play an important role in this bacterial elimination procedure. [14,15]

Mechanical agitation has been found to increase the efficacy of irrigation solutions. 
[16] Different techniques are used for irrigant agitation and are broadly classified as manual (syringe irrigation with needles or cannulae, Endobrush agitation and manual-dynamic agitation) and machine-assisted (rotary brush agitation, continuous irrigation during rotary instrumentation and sonic and ultrasonic agitation) techniques. [17] Among these, passive ultrasonic irrigation (PUI) is considered to be the most effective. [18-20]

Furthermore, many researchers reported that PUI enhances the organic tissue solvent and anti-bacterial properties of sodium hypochlorite ( $\mathrm{NaOCl}$ ) irrigation solution. [17-19]

Following its application in the field of medicine, laser technology has found widespread use in the field of dentistry. [21-23] Its main endodontic applications include root canal shaping, [24] root canal disinfection [25] and endodontic surgery. [26,27] The company Fotona recently introduced a photon-initiated photoacoustic streaming (PIPS) device and claim that this device particularly increases the efficacy of root canal irrigation when mounted on an Er:YAG laser. [28,29]

The aim of this in vitro study was to compare the effectiveness of PUI, EndoActivator agitation, PIPS and manual-dynamic agitation (gutta percha; GP) used during final irrigation with $\mathrm{NaOCl}$ and ethylenediaminetetraacetic acid (EDTA) in the removal of E. Faecalis biofilms from root canals.

\section{METHODS AND MATERIALS}

This in vitro study was approved by the institutional ethics committee of Istanbul University Faculty of Medicine, Turkey (Protocol number 03/366). Extracted for unknown reasons eighty-five single-rooted human maxillary incisors teeth were selected for this study. Immediately after extraction, adherent soft tissue was removed using a scalpel and any adherent hard tissue such as calculus was removed using an ultrasonic scaler. Then, the specimens were stored at $4^{\circ} \mathrm{C}$ distilled water until they were used.
The height of the teeth was standardized to $12 \mathrm{~mm}$ by cutting from the point below the cementoenamel junction using a No. 0.012 diamond fissure bur (Maillefer, SA CH1338, Ballaigues, Switzerland). The working length was calculated as the length of a \#10 K-file (Maillefer, SA CH-1338, Ballaigues, Switzerland) inserted with its tip at the apical foramen, minus $1 \mathrm{~mm}$.

The coronal $3 \mathrm{~mm}$ of all root canals was shaped using an endomotor (X-Smart, Dentsply Maillefer, USA) (1.5 Ncm and $300 \mathrm{rpm}$ ) attached with Endoflare (Micro-Mega, Besancon, France). Before the shaping procedure, the root canals were filled with $2.5 \% \mathrm{NaOCl}$ (Wizard, Rehber Chemicals, Istanbul, Turkey) and prepared with 1-2-mm vertical strokes using Endoflare. Subsequently, the root canals were irrigated with $2 \mathrm{~mL}$ of $2.5 \% \mathrm{NaOCl}$ using a 30-gauge needle (Endo-Eze, Ultradent, South Jordan, UT) with a tip having lateral holes. The same protocol was followed with every tool used after this step. After coronal shaping, the crown-down method was used for canal shaping with SC1 $(25 / 06)$, SC2 (25/04), SU (25/06), AS30 (30/06), AS35 (35/06) and AS40 (40/06), which are files used with the standard Revo-S (Micro Mega, France) Ni-Ti rotary system.

Once canal shaping was complete, 5 $\mathrm{mL}$ of $17 \%$ EDTA (Wizard, Rehber Chemicals, Istanbul, Turkey) was injected into the canals for 1 min using a 30-gauge needle with a tip having lateral holes for smear layer removal. Then, EDTA was neutralized by irrigation with 5 $\mathrm{mL}$ of $2.5 \% \mathrm{NaOCl}, 5 \mathrm{~mL}$ of distilled water and, finally, $5 \mathrm{~mL}$ of $10 \%$ sodium thiosulfate. The apical foramen was subsequently sealed using flowable composite resin (3M Esthete X Flow, Dentsply Maillefer, USA).

The prepared samples were embedded in acrylic resin (Imicryl 0-80, powder-liquid acrylic, Konya, Turkey) for an easy grip, with threefourth of the root in the block and one-fourth outside. All prepared samples were sterilized in a B-type autoclave (Lina, WH, Austria) at $121^{\circ} \mathrm{C}$ and $1 \mathrm{~atm}$ pressure for $15 \mathrm{~min}$. 
Five of the total 85 teeth included in our study were randomly selected as a negative control group. Their access cavities were sealed with a temporary filling material, and the teeth were kept in an oven at $37^{\circ} \mathrm{C}$ for 7 days under aerobic conditions. For the determination of any growth in these control samples, the temporary filling material was removed under sterile conditions on the second, fourth and sixth days and fresh trypticase soy broth (TSB) was added to the root canals. No additional procedures were applied for these samples. The remaining 80 root canals were incubated with an $E$. faecalis (ATCC 29212) strain obtained from the American Type Culture Collection. The bacteria were first inoculated in trypticase soy agar (TSA) and incubated at $37^{\circ} \mathrm{C}$ for $24 \mathrm{~h}$ under aerobic conditions. Growing bacterial colonies were collected and inoculated in TSB medium, and 5 $\mu \mathrm{L}$ of the bacterial suspension $(8 \times 109$ colonyforming unit $[\mathrm{CFUs}] / \mathrm{mL}$ ) was applied to the mechanically widened root canals using sterile micropipettes and spread using sterile ISO \#30 K-files. The access cavities were closed with a temporary filling material (Coltosol®, Coltene, Whaleden). All samples were then placed in an oven at $37^{\circ} \mathrm{C}$ for 7 days in a humid environment under aerobic conditions. The temporary filling material was removed on the second, fourth and sixth days and fresh TSB was added to the root canals. In order to determine the possible biofilm formation, five of the 80 teeth were randomly selected as a positive control group and sent to the Oral Microbiology Laboratory at Istanbul University Faculty of Dentistry and the Nanobiotechnology Laboratory at Yeditepe University Faculty of Engineer and Architect. The colonies in TSA were counted and CFUs per millilitre were calculated (263.3 × 104 CFUs/ $\mathrm{mL}$ ) in Oral microbiology laboratory and one tooth of positive control group was analysed for biofilm development by scanning electron microscope (SEM) (Zeiss, Jena, Germany) in Nanobiotechnology laboratory.

The remaining 75 teeth were randomly divided into five experimental groups ( $\mathrm{n}=15$ each). These teeth were irrigated with $5 \mathrm{~mL}$ of
$5 \% \mathrm{NaOCl}, 5 \mathrm{~mL}$ of $17 \%$ EDTA and, finally, 5 $\mathrm{mL}$ of $5 \% \mathrm{NaOCl}$ using a 30-gauge needle with a tip having lateral holes. Different agitation techniques as described below were applied after each irrigant application, following which the root canals were irrigated with $5 \mathrm{~mL}$ of distilled water and $5 \mathrm{~mL}$ of $10 \%$ sodium thiosulfate. Any residual irrigant was removed.

Group 1 included 15 teeth that received manual-dynamic agitation with Gutta Percha (GP) (Gapadent, Tian Jin City, China). After using each solution, a \#25/06 GP point was inserted up to $2 \mathrm{~mm}$ short of the working length and $1001-2-\mathrm{mm}$ vertical strokes from the apical to the coronal ends were applied for 60s.

Group 2 included 15 teeth that received PUI. In order to maintain PUI during irrigation, the irrigants were used in three volumes of 1 $\mathrm{mL}, 1 \mathrm{~mL}$, and $3 \mathrm{~mL}$. PUI was performed using an ultrasonic device (Electro Medical Systems, EMS, Switzerland) with a \#30 probe mounted on its tip and adjusted to a power of $6 / 10$. The irrigation probe was placed $2 \mathrm{~mm}$ short of the working length, activated and applied using apicocoronal movements. This procedure was applied for $20 \mathrm{~s}$ with each irrigant volume, with a 5-s interval between applications, leading to total activation duration of $60 \mathrm{~s}$. The procedure was repeated three times.

Group 3 included 15 teeth that received EndoActivator (Dentsply Tulsa Dental, Tulsa, OK, USA) agitation. In order to maintain sonic agitation during irrigation, the irrigants were used in three volumes of $1 \mathrm{~mL}, 1 \mathrm{~mL}$, and 3 $\mathrm{mL}$. Sonic agitation was performed using an EndoActivator with a \#30 probe mounted on its tip and adjusted to a power of $10000 \mathrm{cpm}$. The irrigation probe was inserted $2 \mathrm{~mm}$ short of the working length, activated and applied using apicocoronal movements. This procedure was applied for $20 \mathrm{~s}$ with each irrigant volume, with a 5-s interval between applications, leading to a total activation duration of $60 \mathrm{~s}$. The procedure was repeated three times.

Group 4 included 15 teeth that received agitation with PIPS. In order to maintain laser 
agitation during irrigation, the irrigants were used in three volumes of $1 \mathrm{~mL}, 1 \mathrm{~mL}$, and 3 $\mathrm{mL}$. Laser agitation was performed using an Er:YAG laser (Fidelis; Fotona, Slovenia) with a $12-\mathrm{mm}$-long conical probe having a $400-\mu \mathrm{m}$ diameter mounted on its tip and adjusted to15 $\mathrm{Hz}, 0.45 \mathrm{~W}$, a $30-\mathrm{mJ}$ power and a $50-\mu$ s pulse. The irrigation probe was placed $2 \mathrm{~mm}$ short of the working length, activated and applied using apicocoronal movements. This procedure was applied for $20 \mathrm{~s}$ with each irrigant volume, with a 5-s interval between applications, leading to a total activation duration of $60 \mathrm{~s}$. The procedure was repeated three times.

Group 5 included 15 teeth that received conventional syringe irrigation with no agitation. A 30-gauge needle tip (Endo-Eze, Ultradent, South Jordan, UT) having lateral holes was placed without pressure up to $2 \mathrm{~mm}$ short of the apex and applied using apicoronal movements for $60 \mathrm{~s}$.

Next, the root canal wall in each sample was cleaned using a \#30 H-file (Maillefer, SA CH-1338, Ballaigues, Switzerland), following which sterile \#30 paper points were inserted for $15 \mathrm{~s}$. The samples thus obtained were assessed for the number of CFUs in TSA.

All statistical analyses were performed using SPSS Statistics software version 22.0 (IBM SPSS, Turkey). The Mann-Whitney U test was used for pair-wise comparisons of parameters between the experimental and positive control groups, while Kruskal-Wallis and post-hoc Mann-Whitney U multiple comparison tests were used for comparing the residual bacterial counts among the experimental groups. A p-value of $<0.05$ was considered statistically significant.

\section{RESULTS}

No growth was determined in the negative control samples. E. faecalis elimination was detected at various levels in all experimental groups and was significantly better than that in the positive control samples $(\mathrm{p}<0.01)$ (Table 1$)$.
All agitation techniques significantly decreased the number of bacterial cells in the infected root canals ( $\mathrm{p}<0.001)$. The bacterial count in group 1 was significantly higher than that in groups 2,3 and 4 ( $p<0.01$ ), while that in group 5 was significantly higher than that in groups $2(\mathrm{p}=0.011), 3(\mathrm{p}=0.006)$ and $4(\mathrm{p}$ $=0.011$ ) (Figure 1 and 2).
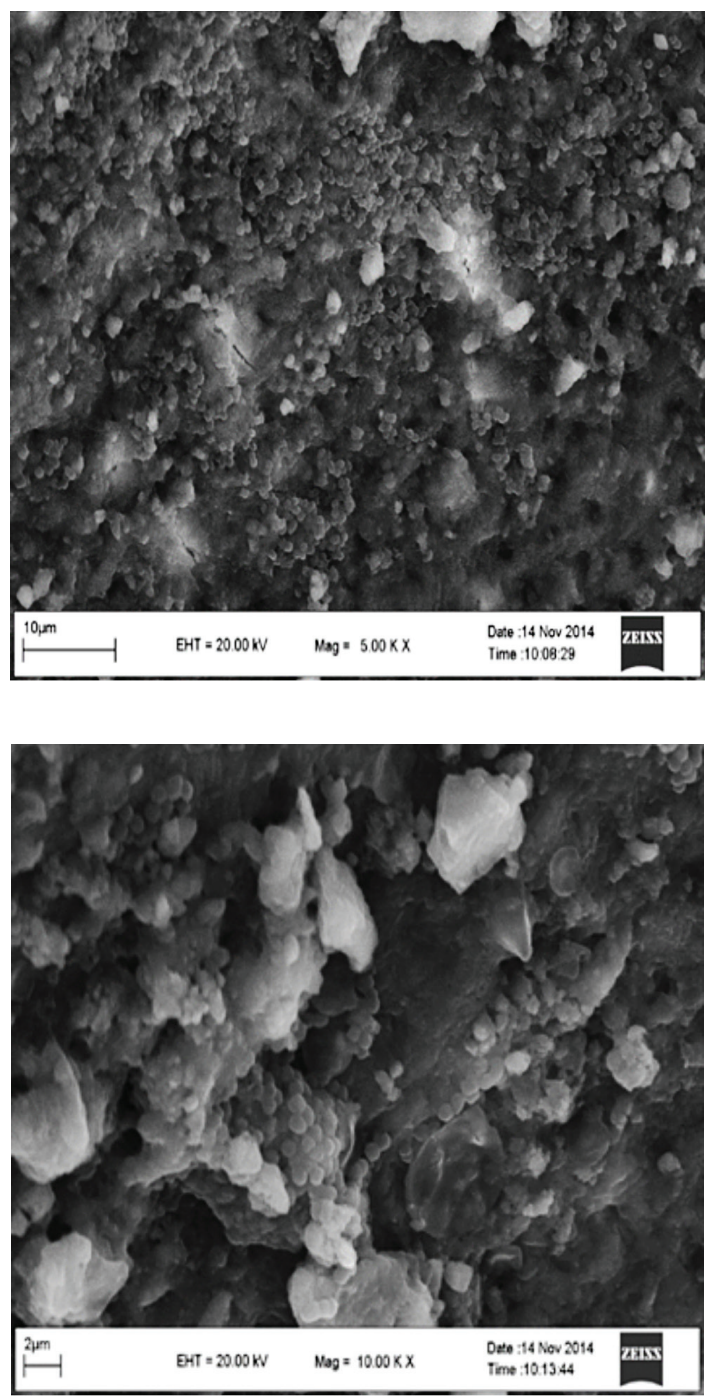

Figure 1 - The development E.faecalis biofilm of root canal walls in positive control group; original magnification, 5000x (A) and 10000x (B). 


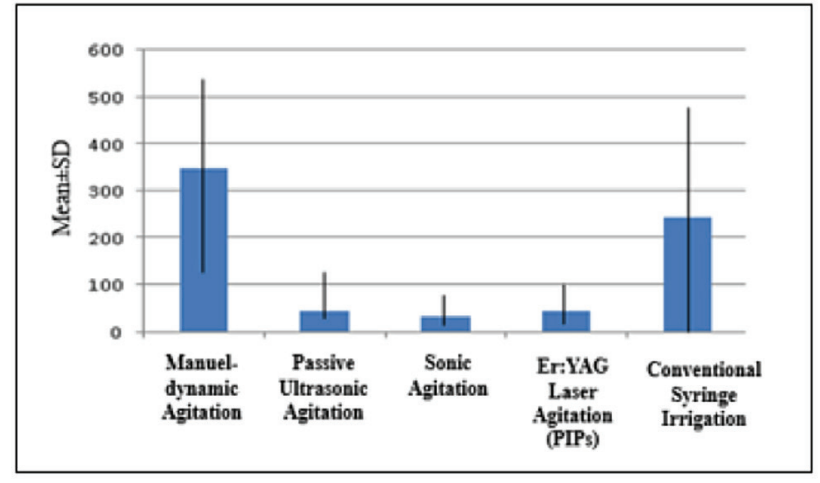

Residual Bacterial Counts

Figure 2 - Means and Standard Deviations of the residual bacterial count values after using the different final irrigation agitation technique.

Furthermore, there were no significant differences between groups 1 and $5(\mathrm{p}=0.108)$, groups 2 and $3(\mathrm{p}=0.937)$, groups 2 and $4(\mathrm{p}$ $=0.476)$ and groups 3 and $4(\mathrm{p}>0.05)$.

Table 1 - Mean and Standard Deviation (SD) values and results of comparison between bacterial count scores for experimental groups

\begin{tabular}{|c|c|c|c|}
\hline Experimental Groups & Mean $\pm S D$ & Median & Pvalue $^{\star}$ \\
\hline $\begin{array}{l}\text { Positive Control } \\
\text { Group }\end{array}$ & $263333,33 \pm 198494,33$ & 200000 & \multirow{6}{*}{$<0.001$} \\
\hline $\begin{array}{l}\text { Manuel-dynamic } \\
\text { Agitation }\end{array}$ & $348.24 \pm 201$ & 340 & \\
\hline $\begin{array}{l}\text { Passive Ultrasonic } \\
\text { Agitation }\end{array}$ & $42.5 \pm 74,43$ & 20 & \\
\hline Sonic Agitation & $31.25 \pm 41,29$ & 20 & \\
\hline $\begin{array}{l}\text { Er:YAG Laser } \\
\text { Agitation }\end{array}$ & $44.71 \pm 54,10$ & 20 & \\
\hline $\begin{array}{c}\text { Conventional } \\
\text { Syringe Irrigation }\end{array}$ & $244 \pm 234$ & 200 & \\
\hline
\end{tabular}

Kruskal Wallis Test ${ }^{*} \mathrm{p} \ll 0.01$

\section{DISCUSSION}

In this study, we compared the effectiveness of four different irrigant agitation techniques used with $\mathrm{NaOCl}$ and EDTA in the removal of $E$. faecalis biofilms from root canals: manual-dynamic agitation, PUI, EndoActivator agitation and PIPS. We found that all agitation techniques significantly decreased the number of bacteria in the infected root canals, with manual-dynamic agitation and conventional syringe irrigation with no agitation showing the least favourable results.

Gram-positive facultative anaerobes are frequently observed in cultures of samples obtained from root canals with failed endodontic treatment. [8,30,31] We selected E. faecalis for our study because its elimination is extremely challenging, it penetrates deep into the dental tissues, it can survive even in negative conditions and it is resistant to intracanal medicaments. $[11,32,33]$

Irrigation performed with mechanical cleaning and shaping of root canals constitutes one of the most important stages of root canal treatment. [6] However, conventional chemomechanical preparation methods appear adequate for the total elimination of microorganisms from root canals. [34-36] The anti-bacterial effects of current irrigation solutions have been reported to be enhanced by increasing the concentration, temperature and amount of solution and by agitation. $[37-39,40]$ Several clinicians reported that irrigant agitation increases the anti-bacterial efficacy and minimizes the rate of treatment failure and persistent infection. [29,41,43]

Previous studies reported that the vapour lock effect of irrigants did not allow the solution to reach the apical region of canals, inhibiting thorough chemomechanical preparation. [44] Manual-dynamic agitation with GP applied exclusively with conventional syringe irrigation was found to eliminate the vapour lock effect through hydrodynamic effects. [45] Furthermore, EndoActivator, which is a sonic device, was found to increase the efficacy of disinfection through oscillations and vibrations, $[15,46]$ while PUIs exhibited similar effects through acoustic currents and cavitation formed by the ultrasonic waves in irrigants. [19,47] Recent years witnessed the introduction of a laser probe mounted on the tip of an Er:YAG laser that was specifically designed for root canal irrigation; this agitation procedure is known 
as PIPS. [28,29,48,49] Different irrigation solutions can be agitated using PIPS, and several studies have shown that this method provides effective disinfection. [50,51] PIPS uses the conventional laser dose and energy at low levels and minimizes the toxic effects of lasers on healthy tissues. [29,51,52]

Various methods have been used for the evaluation of the different irrigant agitation methods, including scanning electron microscopy (SEM), [53,54] CFU counting $[33,55]$ and molecular polymerase chain reaction (PCR). [56] SEM and PCR are very expensive techniques with average results; therefore, we used CFU counting in our study, which is also preferred by several researchers for its increased practicality and precision and easy implementation. [28,48,55]

Although the agitation techniques used in our study significantly decreased the residual bacterial counts in the root canals, none were able to eliminate the bacteria completely. This finding is consistent with those of previous studies, which demonstrated that root canals cannot be completely cleaned of microorganisms, regardless of the method of chemomechanical preparation. $[5,35,57,58]$ In our study, there were no significant differences in bacterial counts among PUI, EndoActivator agitation and PIPS, whereas significant differences were observed between these methods and manualdynamic agitation and conventional syringe irrigation. Nevertheless, the four agitation methods used in this study were $\geq 98 \%$ successful in the elimination of E. faecalis biofilms from root canals, a finding compatible with that in previous studies reporting that a good irrigation technique can significantly decrease the bacterial count in root canals. [43,54,59-61]

\section{CONCLUSIONS}

Within the limitations of this in vitro study, the results suggest that PUI, EndoActivator and PIPS are considerably effective in the removal of E. faecalis biofilms from root canals. Furthermore, our results suggest that conventional irrigation methods and the methods discussed in this study show nearly the same effectiveness in the elimination of bacterial biofilms from root canals, and we believe that the irrigation solution itself maybe an important factor contributing to success. However, this study was based on an artificially induced biofilm under in vitro conditions, and biofilms formed in actual intraoral conditions may show different characteristics. Further similar studies conducted in vivo are necessary to clarify our findings and provide more realistic results.

\section{ACKNOWLEDGEMENT}

The authors would like to thank EndoActivator Dentsply Tulsa Dental, Tulsa, OK, USA and Er:YAG laser F Fotona, Fidelis, Slovenia for the kindly and generous provision of the agitation techniques and materials used.

\section{Clinical Relevance}

Endodontic treatment failures are commonly microbiological problems and crown fractures. If we can remove the biofilms from root canals, the microbiological goals of endodontic treatment will be successful. Different final agitation techniques must clean the dirty canal walls perfectly so that clinical use of these four agitation techniques would practically, successfully and efficiently to remove the biofilms.

\section{REFERENCES}

1. KakehashiS, Stanley HR, Fitzgerald RJ. The effects of surgical exposures of dental pulps in germ-free and conventional laboratory rats. Oral Surg Oral Med Oral Pathol. 1965 Sep;20:340-9.

2. Stabholz A, Zeltser R, Sela M, PeretzB, Moshonov J,Ziskind D. The use of lasers in dentistry: principles of operation and clinical applications. Compend Contin Educ Dent. 2003 Dec;24(12):935-48; quiz 949.

3. Sjogren U, Figdor D, Persson S, Sundqvist G. (1997) Influence of infectionat the time of root filling on the outcome of endodontic treatment of teeth with apical periodontitis. Int Endod J. 1997 Sep;30(5):297-306.

4. Nair PN, Henry S, Cano V, Vera J. Microbial status of apical root canal system of human mandibular first molars with primary apical periodontitis after "onevisit" endodontic treatment. Oral Surg Oral Med Oral Pathol Oral Radiol Endod. 2005 Feb;99(2):231-52.

5. Öter B, Topçuog Lu N, Tank MK, Çehreli SB. Evaluation of Antibacterial Efficiency of Different Root Canal Disinfection Techniques in Primary Teeth. Photomed Laser Surg.2018 Apr;36(4):179-184. doi: 10.1089/pho.2017.4324. Epub2018 Feb26. 
6. Gulabivala K, Patel B, Evans G, Ng YL. Effects of mechanical and chemical procedureson root canal surfaces. Endod Top. 2005;10(1):103-22.

7. Fan B, Min Y,Lu G, Yang J, Cheung GS, Gutmann JL Negotiation of C-shaped canal systems in mandibular second molars. J Endod. 2009 Jul;35(7):1003-8. doi:10.1016/j.joen.2009.04.011.

8. Molander A, ReitC,Dahlén G, Kvist T. Microbiological status of root-filled teeth with apical periodontitis. Int Endod J. 1998 Jan;31(1):1-7.

9. Evans M, Davies JK, Sundqvist G, Figdor D. Mechanisms involved in the resistance of Enterococcus faecalisto calcium hydroxide. IntEndod J.2002 $\operatorname{Mar} ; 35(3): 221-8$

10. Siqueira JF Jr, Rôças IN. Polymerase chain reaction-based analysis of microorganisms associated with failed endodontic treatment. Oral Surg Oral Med Oral Pathol Oral Radiol Endod. 2004 Jan;97(1):85-94.

11. Sun X, LiS, Wang S, Luo C, Hou B. The evaluation of E faecalis colonies dissolution ability of sodium hypochlorite in microenvironment by a novel device. Biomed Microdevices. 2018 Apr 12;20(2):36. doi: 10.1007/s10544-0180279-3.

12. Leonardo MR, Tanomaru Filho M, Silva LA, Nelson Filho P,Bonifácio KC, Ito IY.In vivo antimicrobial activity of $2 \%$ chlorhexidine used as a root canal irrigating solution. JEndod. 1999 Mar;25(3):167-71.

13. Svensater G, Bergenholtz G. Biofilms in endodontic infections. Endod Top. 2004:9(1):27-36.

14. Haapasalo M, Shen Y, Qian W, Gao Y. Irrigation in endodontics. Dent Clin North Am.2010 Apr;54(2):291-312. doi:10.1016/j.cden.2009.12.001.

15. Seet AN, Zilm PS, Gully NJ, Cathro PR. Qualitative comparison of sonic or laser energisation of 4\%sodium hypochlorite on an Enterococcus faecalis biofilm grown in vitro. AustEndod J.2012 Dec;38(3):100-6. doi: 10.1111//.17474477.2012.00366.x. Epub 2012 Jul 16.

16. Saber Sel-D, Hashem AA. Efficacy of different final irrigation activation techniques on smear layer removal. JEndod. 2011Sep;37(9):1272-5. doi: 10.1016/j.joen.2011.06.007.Epub2011 Jul 16.

17. Gu Ls, Kim JR, Ling J, Choi KK, Pashley DH and Tay FR. Review of contemporary irrigant agitation techniques and devices. JEndod. 2009 Jun;35(6):791-804 doi: 10.1016/j.joen.2009.03.010.

18. Plotino G,Pameijer CH, Grande NM, Somma F.Ultrasonics in endodontics: a review of the literature. J Endod. 2007 Feb;33(2):81-95.

19. Van der Sluis $\mathrm{LW}$,Versluis $\mathrm{M}$, Wu MK, Wesselink PR. Passive ultrasonic irrigation of the root canal: a review of the literature. IntEndod J.2007 Jun;40(6):415-26. Epub 2007 Apr 17.

20. CastagnaF, Rizzon P, da Rosa RA, Santini MF, Barreto MS, Duarte MA, etal. Effect of passive ultrassonic instrumentation as a final irrigation protocol on debris and smear layer removal--a SEM analysis. Microsc Res Tech. 2013 May;76(5):496-502. doi:10.1002/jemt.22192. Epub 2013 Mar 1.

21. Lukac M, Primc NM, PirnatS. Quantum square pulse Er:YAG lasers for fast and precise hard dental tissue preparation. J Laser Health Acad. 2012;1:14-21.

22. Maden I. Lasers in Periodontology and Implantology. Journal of the Laser and Health Academy 2013;1:5

23. Manuskiatti W. Treatment of common pigmentary problems in Asians with Q-switched Nd:YAG laser.J Laser Health Acad. 2013;1:S18.

24. Kokuzawa C, Ebihara A, Watanabe S, Anjo T, Bolortuya G, Saegusa H, etal. Shaping of the root canal using Er:YAG laser irradiation. Photomed Laser Surg. 2012 Jul;30(7):367-73. doi: 10.1089/pho.2012.3226. Epub 2012 Jun 12
25. Schoop U, Kluger W,Moritz A, Nedjelik N, Georgopoulos A, Sperr W. Bactericidal effect of different laser systems in the deep layers of dentin. Lasers Surg Med. 2004;35(2):111-6.

26. De Moura AA, Moura-Netto C, Barletta FB, Vieira-Júnior ND, Eduardo Cde P Morphological assessment of dentine and cementum following apicectomy with Zekrya burs and Er:YAG laser associated with direct and indirect Nd:YAG laser irradiation. Oral Surg Oral Med Oral Pathol Oral Radiol Endod. 2010 Apr;109(4):e77-82 doi:10.1016/j.tripleo.2009.12.032.

27. Zerbinati LP, Tonietto L, de Moraes JF, de Oliveira MG. Assessment of marginal adaptation after apicoectomy and apical sealing with Nd: YAG laser. Photomedicine and Laser Surgery 2012;30(8):444-50.

28. PedullaE,Genovese C,Campagna E, Tempera G, RapisardaE.Decontamination efficacy of photon-initiated photoacoustic streaming (PIPS) of irrigants using low-energy laser settings: an ex vivo study. Int Endod J. 2012 Sep;45(9):865-70. doi: 10.1111/.1365-2591.2012.02044.x. Epub2012 Apr 5.

29. Ozses Ozkaya B, Gulsahi K, Ungor M, Gocmen JS. A Comparison of Er:YAG Laser with Photon-Initiated Photoacoustic Streaming, Nd:YAG Laser, and Conventional Irrigation on the Eradication of Root Dentinal Tubule Infection by Enterococcus faecalisBiofilms: A Scanning Electron Microscopy Study. Scanning.2017 Nov 27;2017:6215482 doi: 10.1155/2017/6215482 eCollection 2017.

30. Gomes BP,Drucker DB, Lilley JD. Positive and negative associations between bacterial species in dental root canals. Microbios. 1994;80(325):231-43.

31. Sundqvist G, Fidgor D, PerssonS, Sjogren U. Microbiology analyses of teeth with endodontic treatment and the outcome of conservative re-treatment Oral Surg Oral Med Oral Pathol Oral Radiol Endod. 1998 Jan;85(1):86-93.

32. Giard JC, Hartke A, Flahaut S, Benachour A, Boutibonnes P, Auffray Y. Starvation-induced multiresistance in Enterococcus faecalis.JH2-2. Curr Microbiol. 1996 May;32(5):264-71

33. Shen Y,Stojicic S, Haapasalo M. Bacterial viability in starved and revitalized biofilms: comparison of viability staining and direct culture.J Endod. 2010 Nov;36(11):1820-3. doi: 10.1016/j.joen.2010.08.029. Epub2010 Sep 20.

34. D'Arcangelo C, Varvara G, De Fazio P. An evaluation of theaction of different root canal irrigants on facultative aerobic, anaerobic, obligate anaerobic and microaerophilic bacteria. J Endod. 1999 May;25(5):351-3.

35. SprattDA, Pratten J, Wilson M, Gulabivala K. An in vitro evaluation of the antimicrobial efficacy of irrigants on biofilms of root canal isolates. Int Endod $\mathrm{J}$. 2001Jun;34(4):300-7.

36. Stojicic S, Shen Y, Qian W, Johnson B, Haapasalo M. Antibacterial and smear layer removal ability of a novel irrigant, QmiX. Int Endod J. 2012 Apr;45(4):36371. doi:10.1111/.1365-2591.2011.01985.x. Epub 2011 Nov 16.

37. Abou-Rass M, Oglesby SW. The effects of temperature, concentration, and tissue typeon the solvent ability of sodium hypochlorite. J Endod. 1981 Aug;7(8):376-7.

38. Zehnder M. Root Canal Irrigants. JEndod. 2006 May;32(5):389-98.

39. Stojicic S, Zivkovic S, Qian W, Zhang H, Haapasalo M. Tissue dissolution by sodium hypochlorite: effect of concentration, temperature, agitation and surfactant. JEndod. 2010 Sep;36(9):1558-62. doi: 10.1016/j.joen.2010.06.021.

40. Forough Reyhani M, Rezagholizadeh Y,Narimani MR, Rezagholizadeh L, Mazani M, Barhaghi MHS, et al. Antibacterial effect of different concentrations of sodium hypochlorite on Enterococcus faecalisbiofilms in root canals. J Dent Res Dent Clin DentProspects. 2017 Fall;11(4):215-221. doi:10.15171/ joddd.2017.038. Epub 2017 Dec 13. 
41. Al-Ali M, Sathorn C,Parashos P.Root canal debridement efficacy of different final irrigation protocols. IntEndod J. 2012 0ct;45(10):898-906. doi: 10.1111/.1365-2591.2012.02046.x. Epub2012 Apr 6.

42. Halford A, Ohl CD, Azarpazhooh A, Basrani B, Friedman S, Anil-Kishen A. Synergistic effect of microbubble emulsion and sonic or ultrasonic agitation on endodontic biofilm in vitro. JEndod. 2012 Nov;38(11):1530-4. doi: 10.1016/j. joen.2012.07.007. Epub 2012 Aug 29.

43. Mohmmed SA, Vianna ME, Penny MR, Hilton ST, Mordan N, Knowles JC. A novel experimental approach to investigate the effect of different agitation methods using sodium hypochlorite as an irrigant on the rate of bacterial biofilm removal from the wall of a simulated root canal model. Dent Mater. 2016 Oct:32(10):1289-1300. doi: 10.1016/j.dental.2016.07.013. Epub2016 Aug 8.

44. Schoeffel GJ. The EndoVac method of endodontic irrigation: part2-efficacy Dent Today.2008 Jan;27(1):82, 84, 86-7.

45. McGill S, Gulabivala K, Mordan N, Ng YL The efficacy of dynamic irrigation using a commercially available system (RinsEndo) determined by removal of a collagen 'bio-molecular film' from an ex vivo model. Int Endod J. 2008 Jul;41(7):602-8. doi: 10.1111/j.1365-2591.2008.01408.x. Epub 2008 May 12

46. Bago I,Plečko V, Gabrić Pandurić D, SchauperIZ, Baraba A, Anićl. Antimicrobial efficacy of a high-power diode laser, photo-activated disinfection, conventional and sonic activated irrigation during root canal treatment. Int Endod J.2013 Apr;46(4):339-47. doi:10.1111/.1365-2591.2012.02120.x. Epub 2012 Sep 13.

47. Townsend C,Maki J. An In Vitro Comparison of New Irrigation and agitation techniques to ultrasonic agitation in removing bacteria from a simulated root canal. JEndod. 2009 Jul;35(7):1040-3. doi:10.1016/j.joen.2009.04.007.

48. Peters $\mathrm{OA}$, Bardsley S, Fong J, Pandher G, Divito E. Disinfection of root canals with photon-initiated photoacoustic streaming. J Endod. 2011 Jul;37(7):1008-12. doi:10.1016/j.joen.2011.03.016. Epub 2011May 7.

49. Zhu $X$, Yin X, Chang JWW, Wang Y, Cheung GSP, Zhang C. Comparison of the antibacterial effect and smear layer removal using photon-initiated photoacoustic streaming aided irrigation versus a conventional irrigation in single-rooted canals: an in vitro study. Photomed Laser Surg. 2013 Aug;31(8):371-7. doi:10.1089/pho.2013.3515. Epub 2013 Jul 17.

50. Divito E, Peters $\mathrm{OA}$, Olivi G. Effectiveness of the erbium:YAG laser and new design radial and stripped tips in removing the smear layer after root canal instrumentation. Lasers Med Sci. 2012 Mar;27(2):273-80. doi: 10.1007/s10103010-0858-x. Epub2010 Dec1
51. Olivi G, DiVito E.Photoacoustic Endodontics using PIPS: experimental background and clinical protocol: Review. J Laser Health Acad. 2012;1:22-25.

52. Olivi G, DiVito E, Peters 0, Kaitsas V, Angiero F, Signore A, et al. Disinfection efficacy of photon-induced photoacoustic streaming on root canals infected with Enterococcus faecalis: an ex vivo study. J Am Dent Assoc. 2014 Aug;145(8):843-8. doi:10.14219/jada.2014.46.

53. Wang J, Chen W, Jiang Y, Liang J. Imaging of extraradicular biofilm using combined scanning electron microscopy and stereomicroscopy. Microsc Res Tech. 2013 Sep;76(9):979-83. doi:10.1002/jemt.22257.Epub 2013 Jul 16.

54. Ordinola-Zapata R, Bramante CM, Aprecio RM, Handysides R, Jaramillo DE. Biofilm removal by $6 \%$ sodium hypochlorite activated by different irrigation techniques. IntEndod J. 2014 Jul;:47(7):659-66. doi: 10.1111/iej.12202. Epub 2013 Nov 13.

55. Dos Santos Antonio MP,Moura-Netto C, Camargo SE, DavidowiczH, Marques MM, Maranhão de Moura AA. Bactericidal effects of two parameters of Er:YAG laser intracanal irradiation: ex-vivo study. Lasers Med Sci. 2012 Nov;27(6):11658. doi:10.1007/s10103-011-1023-x. Epub 2011Nov 23.

56. Sakamoto M, Rôças IN, Siqueira JF Jr, Benno Y.Molecular analysis of bacteria inasymptomatic and symptomatic endodontic infections. Oral Microbiol Immunol.2006 Apr;21(2):112-22.

57. Hülsmann M, Rümmelin C, Schäfers F.Root canal cleanliness after preparation with different endodontic handpieces and hand instruments: a comparative SEM investigation.JEndod. 1997 May;23(5):301-6.

58. Ahlquist M, Henningsson 0 , Hultenby $\mathrm{K}$, Ohlin J. The effectiveness of manual and rotary techniques in the cleaning of root canals: a scanning electron microscopy study. Int Endod J.20010ct;34(7):533-7.

59. Dunavant TR, Regan JD, Glickman GN, Solomon ES, Honeyman AL Comparative evaluation of endodontic irrigants against Enterococcus faecalis biofilms. JEndod. 2006 Jun;32(6):527-31.

60. Hockett JL, Dommisch JK, Johnson JD, Cohenca N. Antimicrobial efficacy of two irrigation techniques in tapered and nontapered canal preparations: an in vitro study. JEndod. 2008 Nov;34(11):1374-1377. doi:10.1016/.j.joen.2008.07.022 Epub 2008Sep 3.

61. Mohmmed SA, Vianna ME, Penny MR, Hilton ST, Mordan NJ, Knowles JC. Investigations into in situ Enterococcus faecalis biofilm removal by passive and active sodium hypochlorite irrigation delivered into the lateral canal of a simulated root canal model. Int Endod J.2018 Jun;51(6):649-662. doi: 10.1111/ iej.12880. Epub 2017 Dec 16

Dr.med.dent., Huseyin Gurkan Gunec, Ph.D

(Corresponding address)

University of Beykent

Faculty of Dentistry

Department of Endodontics

Cumhuriyet St Beykent

34550, Istanbul, Turkey

E-mail address: gunec.gurkan@gmail.com

Date submitted: 2018 Jun 14

Accept submission: 2018 Aug 07 